\title{
Nesting habitat selection and challenges of conservation of the vulnerable Lesser Adjutant Leptoptilos javanicus (Horsfield, 1821) in the Chitwan National Park, Nepal
}

\author{
Bishnu Prasad Bhattara ${ }^{1 *}$, Jagan Nath AdHIKARI ${ }^{1,2}$ \\ \& Manukala RIJAL ${ }^{3}$
}

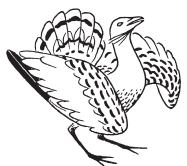

Received: January 08, 2021 - Revised: March 17, 2021 - Accepted: March 18, 2021

Bhattarai, B. P., Adhikari, J. N. \& Rijal, M. 2021. Nesting habitat selection and challenges of conservation of the vulnerable Lesser Adjutant Leptoptilos javanicus (Horsfield, 1821) in the Chitwan National Park, Nepal. - Ornis Hungarica 29(1): 33-46. DOI: 10.2478/orhu-2021-0003

\begin{abstract}
The nesting ecology and conservation threats of the Lesser Adjutant (Leptoptilos javanicus) were studied in the Chitwan National Park, Nepal. We located nine nesting colonies during the nesting season. The number of nests was highly positively correlated with tree height, diameter at breast height and canopy cover. The uppermost canopy of the trees was the most preferred nesting place. Storks preferred to nest in compact colonies on large, widely branched trees with thin foliage cover, such as Bombax ceiba, and also nearby the foraging grounds such as wetlands and grasslands. Storks mostly preferred to nest in Bombax ceiba, but if this tree was not available, they nested in other trees, such as Shorea robusta, Ficus racemosa and Terminalia alata. During the breeding season, 180 adults, 76 nests and 88 chicks were recorded, where the highest number of chicks was recorded near the Sauraha area of the Chitwan National Park. Most of the colonies were far from human settlements, which suggest that human disturbance could be the major determinant of nesting habitat selection in this area. The wetlands nearby human settlements are either overexploited in terms of mass collection of the storks' prey species by people or disturbed highly due to presence of a large number of people. These empirical findings suggest that conservation of Lesser Adjutant mainly rely on the protection of mature Bombax ceiba trees and the reduction of human disturbance and of the collection of stork prey animals from foraging areas.
\end{abstract}

Keywords: Chitwan, conservation threats, Lesser Adjutant, nesting ecology, wetlands

Összefoglalás Az indiai marabu (Leptoptilos javanicus) költésökológiáját és a fajt veszélyeztető tényezőket tanulmányozták egy nepáli vizsgálatban, a Chitwan Nemzeti Parkban. A fészkelési időszak során 9 fészkelőtelepet találtak a területen. A fészkek száma pozitív korrelációt mutatott a fák magasságával, a mellmagasságban mért törzsátmérővel és a lombkorona kiterjedésével. A madarak számára legkedveltebb fészkelőhelynek a felső lombkoronaszint bizonyult. Jellemzően inkább tömör kolóniákban, a széles ágszerkezettel rendelkező, vékony lombozatú fákon - mint pl. a Bombax ceiba - illetve a táplálkozóhelyek - pl. vizes élöhelyek és gyepek - közelében fészkeltek. Preferálták ezt a fafajt, ennek hiányában azonban más fajokat választottak pl. Shorea robusta, Ficus racemosa, Terminalia alata. A költési szezonban 76 fészket, 180 adult egyedet és 88 fiókát számláltak, a legtöbb fiókát a Sauraha régió környékén figyelték meg. A legtöbb telep a településektől távol esett, amiből arra következtettek, hogy az emberi zavarás kiemelt hatással van a fészkelőhelyek kiválasztására a területen. A településekhez közeli vizes élőhelyek túlhasználtak a zsákmányfajok tömegei által, vagy erősen zavartak az emberi jelenlét miatt. Ezek a tapasztalatok azt feltételezik, hogy az indiai marabu megőrzése elsősorban az idős Bombax ceiba fák védelmével, az emberi zavarás és a zsákmányállatok táplálkozási területekről való összegyüjtésének csökkentésével lehetséges.

Kulcsszavak: Chitwan, veszélyeztető tényezők, indiai marabu, költésökológia, vizes élőhelyek 
${ }^{1}$ Central Department of Zoology, Institute of Science and Technology, Tribhuvan University, Kirtipur, Kathmandu, Nepal

${ }^{2}$ Department of Zoology, Birendra Multiple Campus, Bharatpur, Chitwan, Nepal

${ }^{3}$ Himalayan Environment \& Public Health Network, Bharatpur-12, Chitwan, Nepal

*corresponding author, e-mail: bishnu.bhattarai@cdz.tu.edu.np / bhattaraibp@gmail.com

\section{Introduction}

Lesser Adjutant Leptoptilos javanicus (LA) is widely distributed in the Indian subcontinent (de Silva et al. 2015) however, its breeding areas are mostly restricted to smaller patches compared to its non-breeding sites. The colonies of LA most likely occur in farmlands and swampy areas for foraging, however, their nests are found on trees higher than $30 \mathrm{~m}$ far from the foraging grounds (Karki \& Thapa 2013). Therefore, tall trees with wide branches limit the distribution of nesting colonies of this species. LA is listed globally and nationally as vulnerable (Inskipp et al. 2016, BirdLife International 2017), because it has a small and declining population owing to habitat loss and degradation, hunting and disturbance (BirdLife International 2017). However, this species has not yet been listed as a nationally protected bird species by the National Parks and Wildlife Conservation Act of 1973 in Nepal (DNPWC 2020b). The LA is common in southern lowland Nepal, but it has been recorded in larger numbers in and around protected areas, such as Chitwan National Park (CNP), Koshi Tappu Wildlife Reserve (KTWR) and a few in the western Terai regions (Baral 2005, Poudyal \& Nepal 2010, Karki \& Thapa 2013, Baral et al. 2020). LA becomes mature for breeding around three to five years of age and pairs can be seen only during the breeding season (July-October) (Baral 2005, Sundar et al. 2016, 2019).

In the lowlands, croplands dominate (mainly paddy) the most of the landscape as compared to the foraging habitats available inside the protected areas. Forested habitats along with such areas provide a wide array of foraging grounds and nesting sites for wetland-dependent bird species. For example, several water birds such as herons, ibises and storks, show strong preferences for wetlands relative to paddy fields as foraging and breeding habitats, particularly when conditions such as water depth and prey availability are favourable (Fidorra et al. 2016). Generally, population dynamics and foraging behaviour of a colonial nesting species like LA show strong relationships with the quality of natural wetland habitats (Frederick et al. 2009, Sundar et al. 2016), as well as its changes during the nesting seasons (Karki \& Thapa 2013). The nesting season and the ecology of water birds depends on prey availability and threats caused by human activities, such as alternation of wetlands or excessive use of pesticides in croplands (Tozer et al. 2010, Bennett et al. 2018).

Empirical research on LA including use of and dependence upon agricultural landscapes is quite important, since such habitats have been modified by the modernization of agriculture (Adhikari et al. 2019, Choudhary 2019, Lamsal et al. 2019). Therefore, it is necessary to test such relationship between vulnerable water birds like LA and nesting habitat features in human-dominated landscapes. The studies on changes in cropping patterns to a drier monsoonal crop (e.g., hybrid varieties of maize for high production), or reductions in wetlands and availability of taller and wide-branched trees like Bombax ceiba found nearby wetlands and farmlands are necessary for the conservation of such species (Baral 2005, 
Karki \& Thapa 2013). Therefore, this study was designed to fill the gap in understanding of the nesting ecology and factors affecting nesting habitat selection of LA in selected areas of CNP. We examined i) how vegetation structure and habitat parameters associated with nesting colonies, ii) tested whether the nest trees differed from non-nest trees with respect to their structure, and iii) what features of the trees and surrounding environment were important in determining the number of LA nests in a colony.

\section{Materials and Methods}

\section{Study Area}

The Chitwan valley lies in the lowlands of the southern central part of Nepal, which has one of the greatest variety and abundance of wildlife in Asia. The intensive study area located in the core area of the Chitwan National Park (CNP) and Barandabhar Corridor Forest

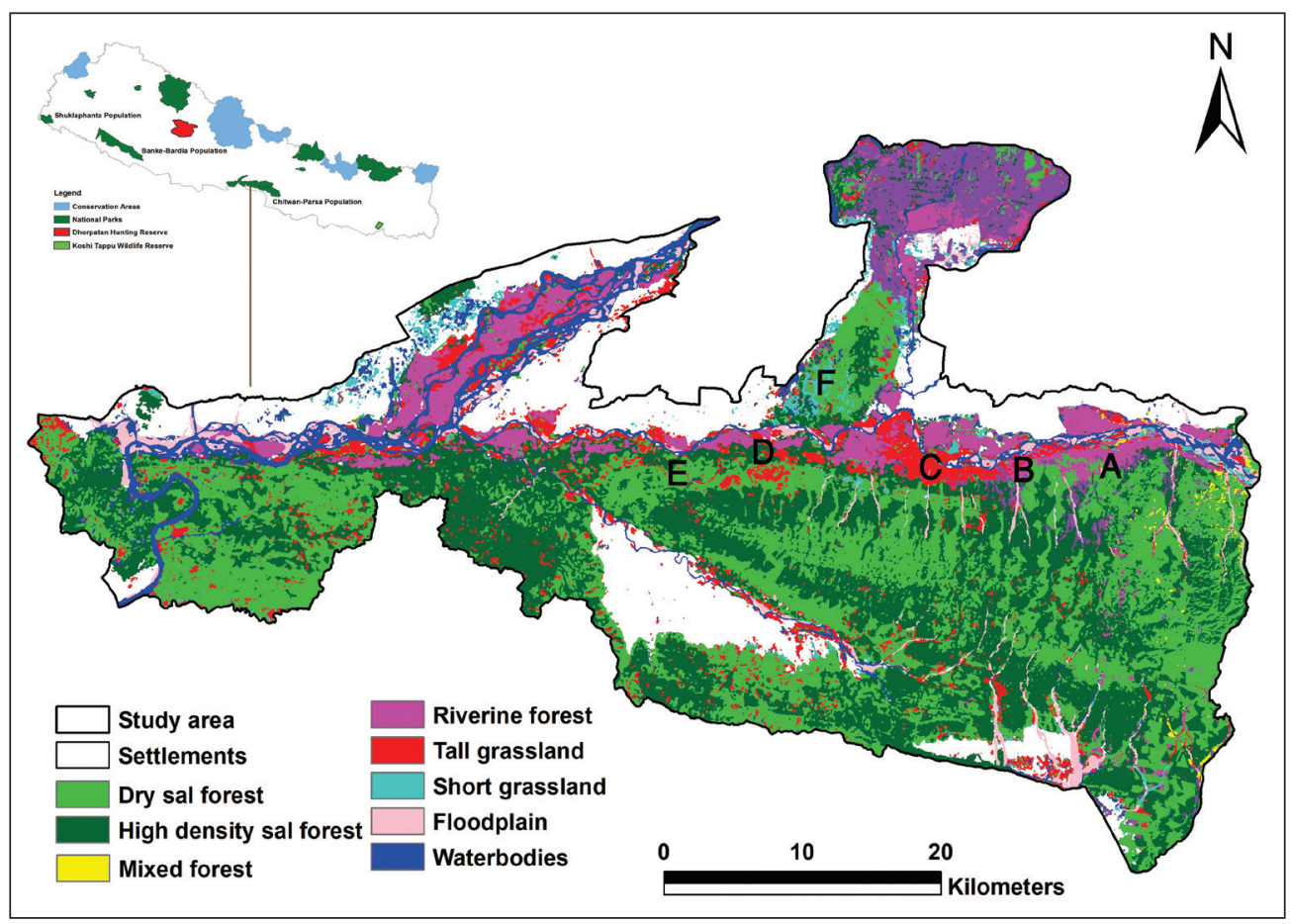

Figure 1. Map of the study area including land cover types and location (A-F) of nesting colonies of LA. Khagendramalli area (A), Old Padampur area (B), Sauraha area (C), Belsar-Dumaria area (D), Ghatgain area (E) and Barandabhar Corridor Forest- bufferzone part of CNP (Beeshazari Lake and associated areas) (F)

1. ábra A vizsgálati terület térképe, beleértve az indiai marabu fészkelőtelepeinek elhelyezkedését $(A-F)$ és az ottani felszínborítást. Khagendramalli régió $(A)$, Old Padampur régió (B), Sauraha régió $(C)$, Belsar-Dumaria régió $(D)$, Ghatgain régió (E) és Barandabhar ökológiai folyosó nemzeti parki pufferzóna (Beeshazari-tó és kapcsolódó területei) (F) 
(BCF), buffer zone part of CNP. CNP (Figure 1) has a core area of $952.63 \mathrm{~km}^{2}$ and a 729.37 $\mathrm{km}^{2}$ buffer zone area, comprising mainly forests (80\%), including Shorea forest, riverine forests and mixed hardwood forests. Besides, there are grasslands (12\%), exposed surfaces (5\%) and water bodies (3\%) (Thapa 2011, DNPWC 2020a). These grasslands (both tall and short) are also a part of the Terai Duar Savana and Grasslands, a Global 200 ecoregion (Wikramanayake et al. 2002). The riverine forest is distributed along the river courses with the large tracks of Bombax ceiba and Khair-Sissoo forest (Bhattarai \& Kindlmann 2012).

The major wetland habitats of the park are the rivers (e.g. Rapti, Budirapti, Khageri), streams, lakes (e.g. Beeshazari, Batulpokhari, Kumal, Tikauli, Nandan, Patna, Tamor, Lami lake), marshlands along the forest patches, seasonal ponds and paddy fields. The CNP provides habitat for more than 68 species of mammals, 544 species of birds, 56 species of reptiles and amphibians and 126 species of fish (CNP 2020). It is also a pristine habitat for migratory birds such as Black Stork (Ciconia nigra) and Woolly-necked Stork (Ciconia episcopus). These birds use this area as a stop-off point (stepping stone) on the way to their ultimate destination (Bhattarai \& Kindlmann 2012a, Inskipp et al. 2016, BirdLife International 2017).

\section{Field Study and Data Collection}

The survey of nesting colonies and threats to conservation of LA was conducted during a breeding season between August 2018 and March 2019. The population count of LA was taken only during the post-breeding season to focus on the maximum records (JanuaryFebruary), which was used for further analysis. We searched for LA and their nesting colonies in the villages and forests along the bird survey routes. The survey routes were located along roads, tracks, river banks and at the periphery of lakes. The nesting colonies were also identified by asking local farmers and nature guides. In each nesting colony, we identified the nesting trees and counted the number and position of nest(s) including presence of chicks in each tree directly in the early morning and evening time, expecting that all birds were present on their nests. Nests were categorized as active or apparently occupied if there was presence of young/chicks or at least one adult in the nest (Bibby et al. 2000). We also checked whether the chicks were fledged or not. For determining the use of nesting habitat and tree, we measured dimensions of tree species, including height of the tree from the ground, diameter at breast height (DBH) and canopy cover area (CCA). The height of the tree and height of the nests were estimated by using Bushnell Range Finder. Canopy cover by each tree species was estimated by measuring canopy spread from the base of the tree trunk in four directions at right angles to each other. Later, the average canopy cover was estimated as the average of the four radii. Besides, we also identified and measured the dimensions of the nearest non-nest tree of greater than $10 \mathrm{~m}$ in height within $20 \mathrm{~m}$ from the base of the nest tree. Likewise, we estimated the nearest distance between nesting trees and the dominant vegetation around each nesting tree.

Furthermore, we also investigated the factors affecting nesting habitat selection of LA such as the distances of other habitat parameters, nearest foraging areas (wetlands, grasslands and croplands), nearest forests, nearest human settlements, nearest road including number of 
livestock, number of people collecting forest and wetland products and number of tourists from the nest tree. We considered nearest forest as either a thick, mixed plantation, often found in villages, or a natural patch of thick vegetation. The nearest foraging grounds were short grasslands, rivers, ponds, lakes or marshes including crop fields.

Separate two sample t-tests for equal means were applied to test the significance of differences between nest and non-nest trees in height, DBH and canopy area, after checking for normality using Shapiro test. The strength of associations between the number of nests and tree structure and also between the number of nests and habitat and disturbance parameters were measured (Lens \& Van Dongen 2000) by linear regression. The auto correlated variables were removed from the analysis after testing Durbin Watson test (Durbin \& Watson 1971). No autocorrelation was detected by checking the values that lie near 2 (1.5 to 2.5). All the analyses were performed in PAST program (Hammer et al. 2001) and $\mathrm{R}$ version 4.0.0. ( $\mathrm{R}$ Core Team 2020).

\section{Results}

\section{Nesting Habitat Selection}

Nine nesting colonies in six locations (Table 1) with a total of 76 active nests in 20 trees were recorded. Most colonies were in the riverine forests and the rest were in the Shorea forests. Bombax ceiba trees in riverine forest possessed the highest number of nesting colonies and nests (Table 1,2). The number and height of the nests were higher in taller trees with larger DBH and canopy cover area at all the sites. Khagendramalli and Ghatgain colonies were nearby village forest borders compared to other colonies. However, Sauraha and BelsarDumaria colonies were far from villages. The highest number of nests were recorded from Dudhaura, Tick plantation site, one and two numbered bridge sites of Sauraha area, while the least number of nests were recorded in the Khagendramalli area having the highest human intervention (Table 2).

Table 1. Locations of the nesting colonies, number of nests and the attributes/characteristics of the nesting trees of Lesser Adjutant in the CNP

1. táblázat Az indiai marabu fészkelőtelepeinek elhelyezkedése, a fészkek száma és a fészkelésre használt fák jellemzői a Chitwan Nemzeti Park területén

\begin{tabular}{|l|c|c|c|c|c|c|}
\hline \multicolumn{1}{|c|}{ Location of Colony } & $\begin{array}{c}\text { No. of } \\
\text { Nest } \\
\text { Trees }\end{array}$ & $\begin{array}{c}\text { No. of } \\
\text { Nests }\end{array}$ & $\begin{array}{c}\text { Height } \\
\text { of Tree } \\
(\mathbf{m} \pm \text { SD) }\end{array}$ & $\begin{array}{c}\text { Height } \\
\text { of Nest } \\
(\mathbf{m} \pm \text { SD) }\end{array}$ & $\begin{array}{c}\text { DBH } \\
(\mathbf{m} \pm \text { SD) }\end{array}$ & $\begin{array}{c}\text { Canopy Cover } \\
\text { Area (m } \mathbf{2} \pm \text { SD) }\end{array}$ \\
\hline Khagendramalli area (A) & 2 & 4 & $29.50 \pm 0.71$ & $27.50 \pm 0.71$ & $1.65 \pm 0.07$ & $328.0 \pm 73.54$ \\
\hline Old Padampur area (B) & 3 & 12 & $31.33 \pm 4.16$ & $27.33 \pm 3.21$ & $2.37 \pm 0.50$ & $587.0 \pm 165.30$ \\
\hline Sauraha area (C) & 6 & 28 & $33.33 \pm 3.20$ & $26.00 \pm 3.58$ & $2.65 \pm 0.55$ & $662.17 \pm 111.69$ \\
\hline Belsar-Dumaria area (D) & 4 & 16 & $32.75 \pm 3.86$ & $26.75 \pm 3.77$ & $2.10 \pm 0.74$ & $665.75 \pm 123.79$ \\
\hline Ghatgain area (E) & 2 & 7 & $30.50 \pm 9.19$ & $26.50 \pm 4.95$ & $1.90 \pm 1.13$ & $556.50 \pm 342.95$ \\
\hline $\begin{array}{l}\text { Barandabhar Corridor } \\
\text { Forest (F) }\end{array}$ & 3 & 9 & $29.67 \pm 3.21$ & $26.33 \pm 4.73$ & $1.80 \pm 0.30$ & $335.0 \pm 35.04$ \\
\hline
\end{tabular}


Table 2. Characteristics of the nesting trees (in Mean \pm SD) used by the Lesser Adjutant in a breeding season (2018-2019)

2. táblázat $\mathrm{Az}$ indiai marabu által fészkelésre használt fák jellemzői (átlag $\pm \mathrm{SD}$ ) a költési szezonban (2018-2019)

\begin{tabular}{|l|c|c|c|c|c|c|}
\hline \multicolumn{1}{|c|}{ Tree Species } & $\begin{array}{c}\text { Number } \\
\text { of Trees }\end{array}$ & $\begin{array}{c}\text { No. of } \\
\text { Nest }\end{array}$ & $\begin{array}{c}\text { Height } \\
\text { of Tree }\end{array}$ & $\begin{array}{c}\text { Height of } \\
\text { Nest }\end{array}$ & DBH & $\begin{array}{c}\text { Canopy Cover } \\
\text { Area }\end{array}$ \\
\hline Bombax ceiba (Simal) & 13 & $4.54 \pm 1.8$ & $33.4 \pm 3.3$ & $26.9 \pm 3.4$ & $2.48 \pm 0.56$ & $676.8 \pm 104.5$ \\
\hline Ficus racemosa (Dumri) & 1 & 1.0 & 24.0 & 23.0 & 1.1 & 314.0 \\
\hline Shorea robusta (Sal) & 4 & $2.5 \pm 0.6$ & $28.5 \pm 2.1$ & $26.0 \pm 3.7$ & $1.77 \pm 0.3$ & $355.7 \pm 47.6$ \\
\hline Terminalia alata (Saj) & 2 & $3.0 \pm 1.4$ & $31.0 \pm 1.4$ & $28.0 \pm 0.7$ & $1.70 \pm 0.14$ & $322.5 \pm 65.8$ \\
\hline
\end{tabular}

During a breeding season in 2016-2017, LA used twenty individual trees of four species for nesting (Table 2). Storks used the same tree for nesting before and during the breeding seasons, as there was only increase in the number of nests. LA mostly used Bombax ceiba (Simal) trees for nesting compared to other trees (Table 2). There were also 20 non-nest trees of six species selected and measured for comparison. Among them, four species (Bombax ceiba, Ficus racemosa, Shorea robusta and Terminalia alata) were the most frequent used as nesting trees. There was significant difference between nesting and non-nesting trees in terms of height $(\mathrm{t}=11.57, \mathrm{P}=0.0001)$ diameter at breast height $(\mathrm{t}=5.89, \mathrm{P}=0.0001)$ and canopy cover area $(\mathrm{t}=5.08, \mathrm{P}=0.0002)$.

In the study area, LA started nesting during the first half of September. During this prebreeding period (September-November), a total of 30 nests and no chicks of LA were

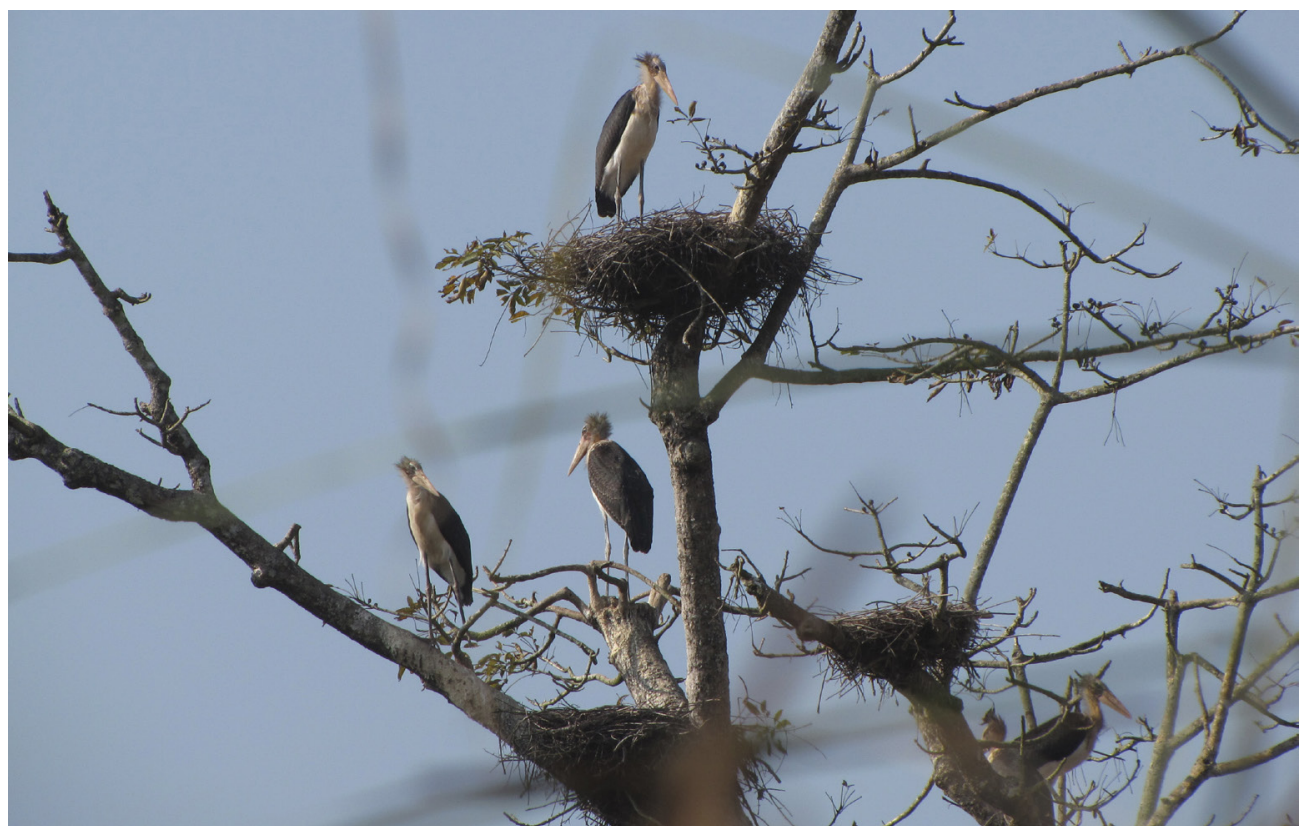

Figure 2. Nests of Lesser Adjutant on Bombax ceiba tree in the Chitwan National Park

2. ábra Indiai marabu fészkek Bombax ceiba fán a Chitwan Nemzeti Parkban 
Table 3. Number of nests, adults of LA and number of chicks during a breeding season 3. táblázat Az indiai marabu fészkek száma, az adult egyedszám és a fiókaszám a költési szezonban

\begin{tabular}{|l|c|c|c|}
\hline \multicolumn{1}{|c|}{ Location } & No. of nests & Adults & Chicks \\
\hline Khagendramalli area (A) & 4 & 37 & 6 \\
\hline Old Padampur area (B) & 12 & 21 & 9 \\
\hline Sauraha area (C) & 28 & 54 & 43 \\
\hline Belsar-Dumaria area (D) & 16 & 31 & 21 \\
\hline Ghatgain area (E) & 7 & 8 & 5 \\
\hline Barandabhar Corridor Forest (F) & 9 & 29 & 4 \\
\hline Total & 76 & 180 & 88 \\
\hline
\end{tabular}

recorded. The highest number of nests were reported in Sauraha area and the lowest in Barandabhar Corridor Forest (Beeshazari and associated areas). However, these numbers were increased during the breeding season (December-February). A total of 180 adults, 76 nests and 88 chicks were recorded in the breeding season. No chicks fledged from the nest during this period; however, this did not mean that the nesting attempts failed, which was not monitored. There were 4 nests with chicks in Khagendramalli area, 6 in Old Padampur area, 23 in Sauraha area, 12 in Belsar-Dumaria area, 3 in Ghatgain area and 3 nests with chicks in Barandabhar Corridor Forest (Figure 2, Table 3). The highest number of chicks was reported in Sauraha area and the lowest number of chicks in Barandabhar Corridor Forest.

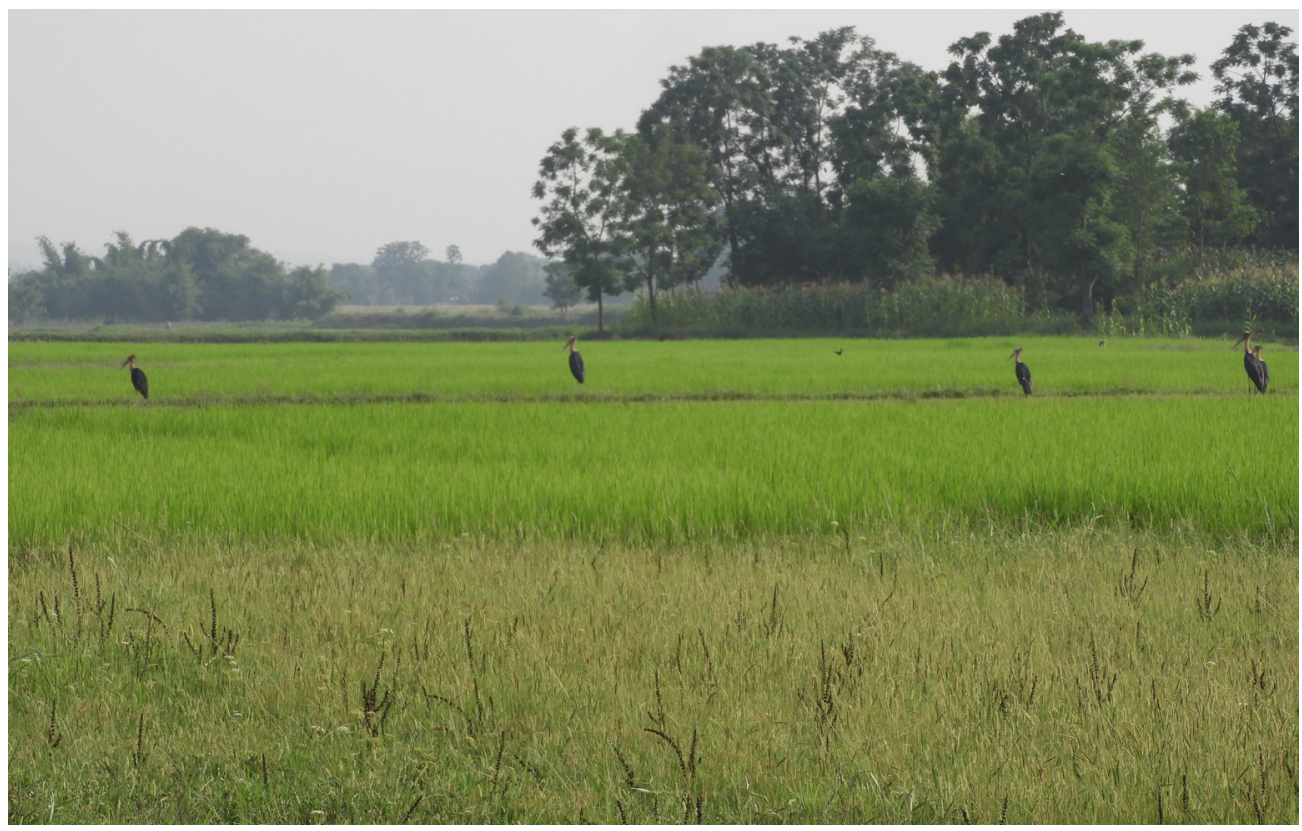

Figure 3. Paddy fields are also the major foraging areas for Lesser Adjutant in the study area 3. ábra Az indiai marabu számára a rizsföldek jelentik a fő táplálkozóhelyeket a vizsgálati területen 
Table 4. Linear regression showing effects of $\mathrm{DBH}$, height and canopy cover area of nesting tree species on number of nests in the study area

4. táblázat Lineáris regresszió, amely a fészkelésre használt fafajok mellmagassági törzsátmérőjének, magasságának és a lombkorona kiterjedésének a fészkek számára gyakorolt hatását mutatja a vizsgálati területen

\begin{tabular}{|l|c|c|c|c|c|c|c|}
\hline \multirow{2}{*}{$\begin{array}{c}\text { Model } \\
\text { parameters }\end{array}$} & \multirow{2}{*}{$\begin{array}{c}\text { Durbin- } \\
\text { Watson }\end{array}$} & \multicolumn{2}{|c|}{$\begin{array}{c}\text { Unstandardized } \\
\text { Coefficients }\end{array}$} & $\begin{array}{c}\text { Standardized } \\
\text { Coefficients }\end{array}$ & \multirow{2}{*}{$\mathbf{R}^{\mathbf{2}}$} & \multirow{2}{*}{ t value } & $\operatorname{Pr}(>|\mathbf{t}|)$ \\
\cline { 3 - 5 } & & $\mathbf{B}$ & Std. error & Beta & & & \\
\hline DBH & 2.204 & 2.165 & 0.490 & 0.721 & 0.521 & 4.417 & $<0.0001$ \\
\hline HoT & 2.131 & 0.119 & 0.064 & 0.402 & 0.161 & 1.861 & 0.079 \\
\hline CCA & 2.333 & 0.007 & 0.003 & 0.519 & 0.270 & 2.579 & 0.019 \\
\hline
\end{tabular}

Durbin-Watson test was performed to test the autocorrelation and found that there was no autocorrelation as the values lie near 2 (1.5 to 2.5). The strength of the relationship between various parameters of nesting tree species and number of nests were measured by performing linear regression. The result showed that the number of nests of LA significantly positively associated with the height, DBH and canopy cover area of tree species (Figure 3, Table 4).

The present study showed that DBH and canopy cover of nesting tree species were the major determinants of the preference of nesting trees for LA, with high number of nests present in those trees with high $\mathrm{DBH}$ values and canopy cover area.

\section{Factors Affecting Nesting of Storks}

Availability of foraging area: Our results indicated higher number of nests nearby foraging areas including rivers, streams, lakes, ponds and paddy fields (farmlands) ( $F i$ gure 3). The number of nests was negatively correlated with the distance to the nearest wetlands and foraging areas (Durbin-Watson=1.174, $\mathrm{R}^{2}=0.397, \mathrm{~F}=11.851, \mathrm{P}=0.003$ ) (Figure 4).

Habitat Disturbance and Destruction: Human and livestock encroachment inside the forest mainly in grasslands and marshy lands was high that could change the population and behaviour of grassland-dependent birds, such as storks, by decreasing the size of feeding and breeding habitats. The variables, for which the estimated values did not lie near 2 (1.5 to 2.5), were considered as correlated and removed from the analysis.

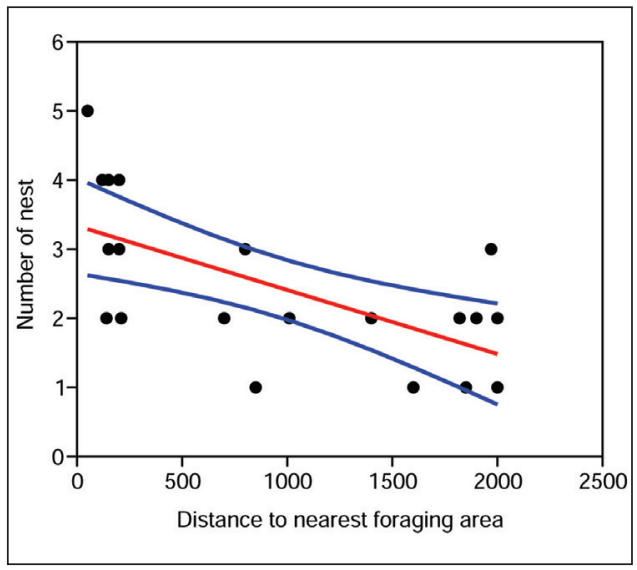

Figure 4. Linear regression between number of nests of LA and distance to nearest foraging areas (paddy fields, wetlands, grasslands)

4.ábra Lineáris regresszió az indiai marabu fészkek száma és a legközelebbi táplálkozóhelyek (rizsföldek, vizes élőhelyek, gyepek) között távolság között 
Table 5. Linear regression showing effects of disturbance variables (nearest village distance-NVD, nearest road distance-NRD), number of people, livestock and tourists on the number of nests (NoN) and population of LA in the study area

5. táblázat Lineáris regresszió, amely a zavaró változók (legközelebbi település távolsága - NVD, legközelebbi úttávolság - NRD), az emberek számának, a haszonállatok számának és a turisták számának hatását mutatja az indiai marabu fészkek számára (NoN) és a faj populációjára a vizsgálati területen

\begin{tabular}{|c|c|c|c|c|c|c|c|}
\hline \multirow{2}{*}{$\begin{array}{c}\text { Model } \\
\text { parameters }\end{array}$} & \multirow{2}{*}{$\begin{array}{l}\text { Durbin- } \\
\text { Watson }\end{array}$} & \multicolumn{2}{|c|}{$\begin{array}{l}\text { Unstandardized } \\
\text { Coefficients }\end{array}$} & \multirow{2}{*}{$\begin{array}{c}\begin{array}{c}\text { Standardized } \\
\text { Coefficients }\end{array} \\
\text { Beta }\end{array}$} & \multirow[t]{2}{*}{$\mathbf{R}^{2}$} & \multirow[t]{2}{*}{ t value } & \multirow[t]{2}{*}{$\operatorname{Pr}(>|t|)$} \\
\hline & & B & Std. error & & & & \\
\hline \multicolumn{8}{|c|}{ With number of nests of LA } \\
\hline NVD & 1.516 & 0.000 & 0.000 & 0.485 & 0.236 & 2.351 & 0.030 \\
\hline No. of people & 2.235 & -0.03 & 0.005 & -0.786 & 0.618 & -5.395 & $<0.0001$ \\
\hline No. of livestock & 1.523 & -0.035 & 0.009 & -0.662 & 0.438 & -3.748 & 0.001 \\
\hline No. of tourists & 2.184 & -0.024 & 0.029 & -0.190 & 0.036 & -0.822 & 0.422 \\
\hline \multicolumn{8}{|c|}{ With population of LA } \\
\hline NRD & 1.561 & 0.020 & 0.007 & 0.590 & 0.349 & 3.104 & 0.006 \\
\hline NVD & 1.569 & 0.003 & 0.001 & 0.702 & 0.493 & 4.187 & 0.001 \\
\hline
\end{tabular}

Significant negative relationship was between the number of nests of LA and the number of people and livestock. There was marginally significant relation with the distance to village. There was no significant relationship between the number of nests and the number of tourists (Table 5). Regarding the population of LA, there was autocorrelation with most of the variables except nearest village distance (NVD) and nearest village distance (NRD). The population of LA showed significant positive correlation with NRD and NVD.

Furthermore, our field observation found that habitat destruction and disturbances caused by human activities and eutrophication were the major threats to them. Per day, we found on average 880 people collecting grass, fodder and firewood; 219 people fishing, collecting molluscs and other wetlands products; 292 foreign tourists and 712 individuals of livestock in and around the wetlands of the study area. Apart from the fishing community, of other people collecting wetland products, 86 were in the Beeshazari and associated lake areas, 36 in the Rapti River, 17 in the Budhi Rapti River, 52 in the Khageri River and 28 in other wetlands inside the forest. Among them, almost all used to collect wetland species such as fishes and molluscs. Some of them, mostly the young ones, involved in the collection of eggs and young birds in the study area, mainly in the Beeshazari lake area and Khageri riversides. In addition, the dense mat of water hyacinth (Eichhornia crassipes) and southern cut grass (Leersia hexandra) in the Beeshazari and associated lakes may trap and kill diving water birds. Because of the dense growth of the water hyacinth, most of the wetlands (mainly lakes and ponds) resembled grasslands. The water level was very low or almost dry in the associated lakes of Beeshazari (e.g. Shorahazar and Satrahazar Lakes), Patna Lake, Nandan lake and other small wetlands inside the forest. 


\section{Discussion}

The present study of the nesting habitat selection of and threats to LA in the Chitwan National Park showed that there were nine nesting colonies and most of them were far from the human-disturbed areas, i.e. human settlements. Most of the colonies were in the riverine forests interspersed with grasslands. LA mostly built their nests in Bombax ceiba trees. This tree is generally bigger and taller than other tree species. A similar result was also obtained by Karki and Thapa (2013) in eastern lowland Nepal. Our results revealed that nest trees were found to be larger and significantly larger in height, DBH and canopy cover as compared to the nearest non-nest trees. Likewise, the number of nests in a tree significantly correlated with tree size (height, DBH and canopy cover area). These results suggest that LA selects taller and bigger trees for nesting. Similar results were obtained by Baral (2005) for LA and other similar species, such Greater Adjutant Leptoptilos dubius (Singha et al. 2002, Sundar et al. 2016, Barman \& Sharma 2020) and Asian Openbill Anastomus oscitans (Sundar et al. 2016, Zainul-Abidin et al. 2017). The larger bird species mostly preferred to nest in taller (Burger 1979) and widely branched trees. In most parts of the study area, we found LA nests in compact colonies. The nearest nest tree distance shows the compact nature of LA colonies. A similar result was also reported by Pomeroy (1977) and Sundar et al. (2016); therefore, such compactness is possible only where sufficient suitable trees are available close together.

The height of the nesting trees varied among nesting colonies, most of the nests being on the top canopy of relatively large and tall trees, which is a common pattern in most of the water birds (Burger 1979, Minias \& Kaczmarek 2013, Koju et al. 2020). Besides, some birds may nest at the top to receive more solar radiation that may affect nest temperature and thus, the amount of incubation required (Martin \& Roper 1988, Slagsvold \& Wiebe 2017). This is also true particularly for the Greater Adjutant, as it breeds in winter (Chowdhury \& Sourav 2012, Slagsvold \& Wiebe 2017). LA built their nests with large platform, and also preferred trees with sparse foliage cover (e.g. Bombax ceiba) at the nest site to make easy access for arrival and departure, similar to that of Greater Adjutant (Mandal \& Saikia 2013). Therefore, trees with horizontal branches or branches slightly inclined parallel to the ground (e.g. not like ' $\mathrm{Y}$ ' fork) were the most preferred tree for LA. Availability of wetlands and change in cropping patters in lowland Nepal was the major determinant of provisioning time for LA. However, in our study area, most of the nesting colonies of LA located far from human settlements and croplands (Baral 2005, Karki \& Thapa 2013).

Nesting activities of LA depended upon various factors, such as availability of foraging grounds, nesting trees and comparatively less disturbed areas. The start of breeding season of LA was found to be later (August/September) compared to the eastern part of Nepal (July/ August) (Baral 2005, Allay 2009, Karki \& Thapa 2013). Breeding of LA was found to be more successful in the core area of CNP as compared to the Barandabhar Corridor Forest. Nests with chicks were reported only in the southern part of Barandabhar Corridor Forest close to the Rapti River and core area of CNP. However, there was no record of nests with chicks in and around the Beeshazari and associated areas despite having good foraging grounds. Our recent observations noticed that there were no nests in the Barandabhar 
Corridor Forest in 2020. It showed the shifting tendency in nesting of LA. In contrary to the argument of Beaver et al. (1980) that availability of suitable tree species influences the dispersion of nests more than other factors, such as social and human disturbances. There were very few Bombax ceiba trees in riverine forest of Barandabhar Corridor Forest as compared to CNP (Thapa 2011, Bhattarai \& Kindlmann 2012). Sauraha area possessed the highest number of nests including chicks and adults.

The study found the highest number of nests in areas that were less disturbed by human activities, such as people presence and livestock grazing. This study suggests that human disturbance limits the location, compactness and number of nesting colonies in the CNP and associated areas (Bhattarai \& Kindlmann 2012, Bhattarai \& Kindlmann 2013). However, in the case of Greater Adjutant colonies, both the availability of suitable nesting trees and social interactions determine the compactness of nesting colonies (Ali et al. 1987, Singha et al. 2002). Earlier studies of Datta and Pal (1993) and Sundar et al. (2016) reported that human disturbance caused the mortality of nestlings of Asian Openbill. A similar scenario might be true for the human-disturbed areas of the CNP and BCF. Unlike other studies (Pomeroy 1977), we did not record felling of trees by local people except a natural felling of Bombax ceiba, common in the CNP during the stormy season (April, May). The nearest road from the nesting colonies had very less impact on the occurrence of nests, because most of these roads were part of the road networks inside the park (e.g. firelines) and used mostly by tourist vehicles and park monitoring for security.

This study found that LA nesting colonies mostly located within $3 \mathrm{~km}$ of foraging areas. It has been considered that the closer distance to the foraging ground enables the storks to increase the number of foraging trips to feed the nestlings. In the study area, the foraging grounds of LA were vulnerable due to presence of people for collection of prey species (molluscs and fishes), a common practice in lowland Nepal (Baral 2005). Fishing communities, such as Tharu, Bote, Darai and Majhi people, are main inhabitants nearby the water sources or forests and highly dependent on the forests and wetlands, a common practice in rural areas (Baral 2005). In contrast, these people mostly visit wetlands of the CNP and adjoining areas during the dry winter season (i.e. nesting season of LA) compared to the rainy season. Wetlands become less suitable for LA due to increased human activities during winter season (Sundar $e t$ al. 2016). The conservation of LA could be successful if we protect large Bombax ceiba trees, minimizing human disturbance including collection of prey species, and raising awareness to reduce human activities harmful to LA. The findings of this research also highlight the lack of empirical research in nesting ecology of LA, including use and dependence upon humandominated agricultural landscapes, such as paddy fields.

\section{Conclusion}

Understandings of nesting ecology and conservation challenges are crucial for management and conservation of threatened bird species like the LA. This study found that the number of nests of storks was highly positively correlated with tree height, diameter at breast height and canopy cover of the trees. LA mostly preferred the uppermost canopy of the trees for 
nesting. The nests were found in compact colonies on large, widely branched trees with thin foliage cover such as Bombax ceiba. In the absence of Bombax ceiba, they built nest on other trees with similar dimension e.g. Shorea robusta, Ficus racemosa and Terminalia alata. Most of the nesting colonies were recorded nearby foraging grounds. There were a total of 180 adults, 76 nests and 88 chicks recorded in the breeding season, in which Sauraha area possessed the highest number of adults and chicks. Most of the nesting colonies were far from human settlements, suggesting that human disturbance could play a major role in nesting habitat selection. These results imply that nesting success of LA mainly rely on the protection of Bombax ceiba trees and their long-term conservation requires minimal human disturbance and sustainable utilization of wetland products, including collection of prey species of storks by fishing communities.

\section{Acknowledgements}

We are thankful to the Department of National Parks and Wildlife Conservation (DNPWC), Chitwan National Park (CNP) and Division Forest Office, DFO-Chitwan for granting permission to conduct the research work. Authors are grateful to Himalayan Environment and Public Health Network (HEPHN) for providing field assistant and technical support during the field work.

\section{References}

Adhikari, J. N., Bhattarai, B. P. \& Thapa, T. B. 2019. Factors affecting diversity and distribution of threatened birds in Chitwan National Park, Nepal. - Journal of Threatened Taxa 11: 13511-13522. DOI: 10.11609/ jott.4137.11.5.13511-13522

Ali, S., Ripley, S. D. \& Dick, J. H. 1987. Compact Handbook of the Birds of India and Pakistan: Together with those of Bangladesh, Nepal, Bhutan and Sri Lanka, 6. ed. - Delhi, Oxford University Press

Allay, B. 2009. Breeding success of Lesser Adjutant Storks (Leptoptilos javanicus) in and around Koshi Tappu Wildlife Reserve, Nepal. - Tribhuvan University, Kathmandu, Nepal

Baral, B., Bhandari, S., Koirala, S., Bhandari, P., Magar, G., Basnet, D. R., Rai, J. \& Baral, H. S. 2020. First distributional record of the Lesser Adjutant Leptoptilos javanicus Horsfield, 1821 (Ciconiiformes: Ciconiidae) from Sindhuli District, Nepal. - Journal of Threatened Taxa 12: 17028-17031. DOI: 10.11609/ jott.4902.12.14.17028-17031

Baral, H. S. 2005. Surveys for Lesser Adjutant Leptoptilos javanicus in and around Koshi Tappu Wildlife Reserve, Nepal. - Forktail 21: 190-193.

Barman, P. D. \& Sharma, D. 2020. Foraging analysis of endangered Greater Adjutant Stork Leptotilus dubios Gemlin in certain habitat of Assam, India. - bioRxiv. DOI: 10.1101/2020.05.31.125328

Beaver, D. L., Osborn, R. G. \& Custer, T. W. 1980. Nest-site and colony characteristics of wading birds in selected Atlantic coast colonies. - The Wilson Bulletin 92(2): 200-220.

Bennett, M. T., Gong, Y. \& Scarpa, R. 2018. Hungry birds and angry farmers: using choice experiments to assess "eco-compensation" for coastal wetlands protection in China. - Ecological Economics 154: 71-87. DOI: 10.1016/j.ecolecon.2018.07.016

Bhattarai, B. P. \& Kindlmann, P. 2012a Habitat heterogeneity as the key determinant of the abundance and habitat preference of prey species of tiger in the Chitwan National Park, Nepal. - Acta Theriologica 57: 89-97. DOI: 10.1007/s13364-011-0047-8

Bhattarai, B. P. \& Kindlmann, P. 2012b Distribution and diversity of storks in the adjoining areas of Chitwan National Park, Nepal. - In: Kildmann, P. (ed.) Himalayan Biodiversity in the Changing World. - Springer, pp. 97-114. DOI: 10.1007/978-94-007-1802-9 4 
Bhattarai, B. P. \& Kindlmann, P. 2013. Effect of human disturbance on the prey of tiger in the Chitwan National Park-implications for park management. - Journal of Environment Management 131: 343-350. DOI: 10.1016/j. jenvman.2013.10.005

Bibby, C. J., Burgess, N. D., Hill, D. A. \& Mustoe, S. 2000. Bird census techniques. $2^{\text {nd }}$ ed. - Elsevier

BirdLife International 2017. Leptoptilos javanicus (amended version of 2016 assessment). - The IUCN Red List of Threatened Species 2017: e.T22697713A110481858. BirdLife International

Burger, J. 1979. Resource partitioning: nest site selection in mixed species colonies of herons, egrets and ibises. American Midland Naturalist 101: 191-210. DOI: 10.2307/2424913

Choudhary, D. 2019. Protecting the Greater Adjutant Stork. - Science Reporter 56: 24-26. http://nopr.niscair.res.in/ handle/123456789/51217

Chowdhury, S. U. \& Sourav, M. 2012. Discovery of a Lesser Adjutant Leptoptilos javanicus breeding colony in Bangladesh. - BirdingASIA 17: 57-59.

CNP 2020. Biodiversity of Chitwan National Park. - Chitwan National Park, Kasara, Chitwan, Nepal

Datta, T. \& Pal, B. 1993. The effect of human interference on the nesting of the Openbill Stork Anastomus oscitans at the Raiganj Wildlife Sanctuary, India. - Biological Conservation 64: 149-154. DOI: 10.1016/00063207(93)90651-G

de Silva, T. N., Fernando, S., de Silva, H. B. \& Tennakoon, P. 2015. Lesser Adjutant Leptoptilos javanicus Horsfield, 1821 (Ciconiiformes: Ciconiidae) in the dry lowlands of Sri Lanka: distribution, ecology, and threats. - Journal of Threatened Taxa 7: 8089-8095. DOI: 10.11609/jott.2425.7.14.8089-8095

DNPWC 2020a National Parks of Nepal. - Department of National Parks and Wildlife Conservation Nepal

DNPWC 2020b Protected Birds of Nepal usder NPWC Act 1973. - Department of National Parks and Wildlife Conservation (DNPWC)

Durbin, J. \& Watson, G. S. 1971. Testing for serial correlation in least squares regression. III. - Biometrika 58: 1-19.

Fidorra, J. C., Frederick, P. C., Evers, D. C. \& Meyer, K. D. 2016. Selection of human-influenced and natural wetlands by Great Egrets at multiple scales in the southeastern USA. - The Condor 118: 46-56. DOI: 10.1650/ CONDOR-14-117.1

Frederick, P., Gawlik, D. E., Ogden, J. C., Cook, M. I. \& Lusk, M. 2009. The White Ibis and Wood Stork as indicators for restoration of the everglades ecosystem. - Ecological Indicators 9: S83-S95. DOI: 10.1016/j. ecolind.2008.10.012

Hammer, Ø., Harper, D. A. \& Ryan, P. D. 2001. PAST: Paleontological statistics software package for education and data analysis. - Palaeontologia Electronica 4: 4-9.

Inskipp, C., Baral, H. S., Phuyal, S., Bhatt, T. R., Khatiwada, M., Inskipp, T., Khatiwada, A., Gurung, S., Singh, P. B. \& Murray, L. 2016. The Status of Nepal's Birds: The National Red List Series. - Zoological Society of London, London, U.K.

Karki, S. \& Thapa, T. B. 2013. Population status, nesting habitat selection and conservation threats of Lesser Adjutant Stork (Leptoptilos javanicus) in the eastern lowlands of Nepal. - Conservation Science 1: 27-35. DOI: 10.3126/cs.v1i1.8581

Koju, R., Maharjan, B., Gosai, K. R., Kittur, S. \& Sundar, K. G. 2020. Ciconiiformes nesting on trees in cerealdominated farmlands: Importance of scattered trees for Heronries in Lowland Nepal. - Waterbirds 42: $355-453$. DOI: $10.1675 / 063.042 .0401$

Lamsal, P., Atreya, K., Ghosh, M. K. \& Pant, K. P. 2019. Effects of population, land cover change, and climatic variability on wetland resource degradation in a Ramsar listed Ghodaghodi Lake Complex, Nepal. Environmental Monitoring and Assessment 191(7): 415. DOI: 10.1007/s10661-019-7514-0

Lens, L. \& Van Dongen, S. 2000. Fluctuating and directional asymmetry in natural bird populations exposed to different levels of habitat disturbance, as revealed by mixture analysis. - Ecology Letters 3: 516-522. DOI: 10.1111/j.1461-0248.2000.00181.x

Mandal, J. \& Saikia, P. K. 2013. Greater Adjutant Storks Leptoptilos dubius Gemlin 1789: Breeding and foraging distribution in Kamrup District, Assam, India. - European Journal of Zoological Research 2: 1-5.

Martin, T. E. \& Roper, J. J. 1988. Nest predation and nest-site selection of a western population of the Hermit Thrush. - The Condor 90: 51-57.

Minias, P. \& Kaczmarek, K. 2013. Is it always beneficial to breed in the centre? Trade-offs in nest site selection within the colony of a tree-nesting waterbird. - Journal of Ornithology 154: 945-953. DOI: 10.1007/s10336013-0960-5

Pomeroy, D. 1977. Marabou Stork Leptoptilos crumeniferus breeding colonies in Uganda. - Journal of the East Africa Natural History Society and National Museum 31: 1-11. 
Poudyal, L. P. \& Nepal, S. 2010. Population status of Lesser Adjutant in Chitwan National Park, Nepal. - Danphe 19: $1-4$.

Singha, H., Rahmani, A. R., Coulter, M. C. \& Javed, S. 2002. Nesting ecology of the Greater Adjutant Stork in Assam, India. - Waterbirds 25: 214-220. DOI: 10.1675/1524-4695(2002)025[0214:NEOTGA]2.0.CO;2

Slagsvold, T. \& Wiebe, K. 2017. On the use of heterospecific information for nest site selection in birds. - Journal of Avian Biology 48: 1035-1040. DOI: 10.1111/jav.01398

Sundar, K. G., Koju, R., Maharjan, B., Marcot, B. G., Kittur, S. \& Gosai, K. R. 2019. First assessment of factors affecting the breeding success of two stork species in lowland Nepal using Bayesian Network models. Wildfowl 69: 45-69.

Sundar, K. G., Maharjan, B., Koju, R., Kittur, S. \& Gosai, K. R. 2016. Factors affecting provisioning times of two stork species in lowland Nepal. - Waterbirds 39: 365-374.

R Core Team 2020. R: A language and environment for statistical computing. - Foundation for Statistical Computing, Vienna, Austria

Thapa, T. B. 2011. Habitat suitability evaluation for Leopard (Panthera pardus) using remote sensing and GIS in and around Chitwan National Park, Nepal. - PhD Thesis, Saurashtra University, Rajkot, India

Tozer, D. C., Nol, E. \& Abraham, K. F. 2010. Effects of local and landscape-scale habitat variables on abundance and reproductive success of wetland birds. - Wetlands Ecology and Management 18: 679-693. DOI: 10.1007/ s11273-010-9187-x

Wikramanayake, E. D., Dinerstein, E. \& Loucks, C. J. 2002. Terrestrial ecoregions of the Indo-Pacific: a conservation assessment. - Island Press

Zainul-Abidin, M. K., Mohd-Taib, F. \& Md-Nor, S. 2017. Distribution and habitat selection of the Asian Openbill (Anastomus oscitans) in Peninsular Malaysia. - Malayan Nature Journal 69: 169-181.

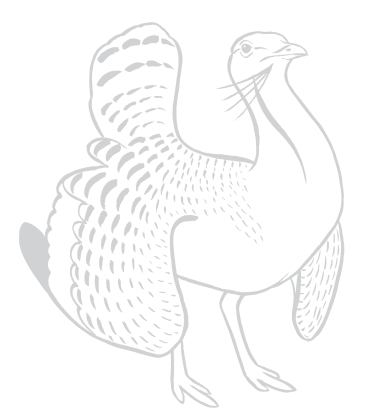

